Tropical Journal of Pharmaceutical Research April 2021; 20 (4): 809-814

ISSN: $1596-5996$ (print); 1596-9827 (electronic)

(C) Pharmacotherapy Group, Faculty of Pharmacy, University of Benin, Benin City, 300001 Nigeria.

\title{
Ambrosin exerts strong anticancer effects on human breast cancer cells via activation of caspase and inhibition of the Wnt/ $\beta$-catenin pathway
}

\author{
Xiangling Meng ${ }^{1 *}$, Zhuling Shao ${ }^{2}$ \\ ${ }^{1}$ Department of General Thoracic Surgery, ${ }^{2}$ Department of Emergency, The Third Linyi People's Hospital, Linyi, Shandong \\ 276000, China
}

*For correspondence: Email: MyahCastroaik@yahoo.com; Tel/Fax: 0086-0539-8769222

Sent for review: 9 April 2020

Revised accepted: 14 March 2021

\begin{abstract}
Purpose: To investigate the antitumor effects of ambrosin sesquiterpene lactone on drug-resistant MDA-MB-231 breast cancer cells.

Methods: The 3-(4,5-dimethylthiazol-2-yl)-2,5-diphenyl tetrazolium bromide (MTT) assay was used for cell viability studies. Apoptotic effects were determined using 4',6-diamidino2-phenylindole (DAPI) staining assay, while Annexin V/PI was used for the quantification of apoptosis. Levels of reactive oxygen species (ROS) were determined by flow cytometry using DCFH-DA fluorescence staining while the effects of ambrosin on apoptosis and Wnt/beta-catenin signaling pathway-allied proteins were evaluated by Western blotting assay.

Results: Ambrosin significantly suppressed the viability of MDA-MB-231 cells in a dose- and timedependent manner $(p<0.05)$. Results from Annexin V/PI staining revealed that ambrosin induced production of apoptotic crops and blebbing of plasma membrane in MDA-MB-231 cells. Furthermore, annexin V/PI assay results showed increases in percentage of cells in different stages of apoptosis. Thus, ambrosin promoted caspase-dependent-apoptosis in MDA-MB-231 cells. Moreover, ambrosin enhanced the formation of ROS in MDA-MB-231 cells, as was evident from increased DCFfluorescence $(p<0.05)$. The results also showed dose-dependent inhibition of Wnt/beta-Catenin signaling pathway by ambrosin.

Conclusion: Ambrosin exerts a chemo-preventive effect on breast cancer cells via induction of programmed cell death, enhanced ROS production, caspase activation and suppression of Wnt/betacatenin signaling. These findings have potential benefits for breast cancer research and drug discovery.
\end{abstract}

Keywords: Breast cancer, Sesquiterpenoids, Ambrosin, Apoptosis, Caspase activation, Wnt/betacatenin signaling pathway

This is an Open Access article that uses a fund-ing model which does not charge readers or their institutions for access and distributed under the terms of the Creative Commons Attribution License (http://creativecommons.org/licenses/by/4.0) and the Budapest Open Access Initiative (http://www.budapestopenaccessinitiative.org/read), which permit unrestricted use, distribution, and reproduction in any medium, provided the original work is properly credited.

Tropical Journal of Pharmaceutical Research is indexed by Science Citation Index (SciSearch), Scopus, International Pharmaceutical Abstract, Chemical Abstracts, Embase, Index Copernicus, EBSCO, African Index Medicus, JournalSeek, Journal Citation Reports/Science Edition, Directory of Open Access Journals (DOAJ), African Journal Online, Bioline International, Open-J-Gate and Pharmacy Abstracts

\section{INTRODUCTION}

Sesquiterpene lactones (SLs) are present in plants as secondary metabolites. They contain $\alpha-$ methylene- $y$-lactone-ring in their structures [1].
Thus, SLs are alkylating in nature, an effect which is enhanced by the presence of $\alpha-$ methylene- $y$-lactone ring. This property enables them to alkylate nucleophiles, including cellular proteins which bear sulfhydryl groups. 
Specifically, SLs target certain proteins e.g. p-65, an associate of heterodimeric transcription factor $\mathrm{NF}-\mathrm{KB}$ which is involved in regulation of several intracellular activities such as invasion, metastasis, angiogenesis, immune responses, survival and proliferation [2,3]. Ambrosin (Figure 1) molecule is a pseudo guanolide SL which occurs naturally and abundantly in ragweed species $[4,5]$. Structurally, ambrosin bears no phenolic moiety and is non-polar in nature. Studies have revealed that ambrosin possesses numerous biological as well as pharmacological properties, including cancer suppression and NFKB inhibition $[6,7]$. In addition, immuno-

histochemical, behavioural and molecular studies have shown that ambrosin exerts suppressive effects on neuro-inflammation, amyloidogenesis and neuronal death [8].

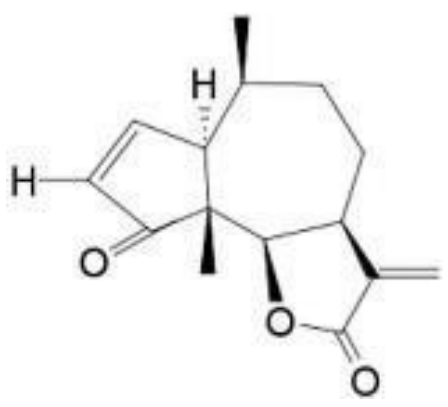

Figure 1: Chemical structure of ambrosin molecule

Breast cancer $(\mathrm{BC})$ is a neoplasm prevalent in females [9]. It is associated with high mortality and morbidity, and its prevalence is on the increase. For example, in the last three decades China, United States, Malaysia and Asian subcontinent experienced nearly $3.1 \%$ increase in overall BC cases, a situation which is very disturbing. Nearly 1.6 million new BC patients were documented globally between 2010 and 2012 [10,11]. The disease is heterogeneous in nature, with respect to histopathology and genetics. Till date, the pathogenesis of $\mathrm{BC}$ has not been fully understood [12]. However, it is known that hormone receptors and HER2 activity influence different BC sub-types such as luminal, HER2 and triple-negative [13]. Genetic mutations in luminal or basal progenitor cells give rise to distinct sub-types which accentuate the lethality of breast cancer. Breast cancer sub-types are also associated with differences in metastasis, biology and management strategies [14].

The treatment options for BC are limited. Moreover, apart from having low efficacy, the available treatment options cause life-threating side-effects. Natural products are of immense pharmacological potential. They have remarkable bioactivity profiles. Indeed, approximately $70 \%$ of current chemotherapeutics are either natural products or compounds based on them, and many more are yet to be discovered [15-20]. Thus, with a knowledge of the potential of ambrosin sesquiterpene, the current study was designed to investigate its effect on breast cancer cells, and its effects on programmed cell death, ROS production, caspases and the Wnt/beta-catenin signaling pathway.

\section{EXPERIMENTAL}

\section{Determination of effect of ambrosin on viability of MDA-MB-3231 BC cells}

The effect of ambrosin on the proliferation of MDA-MB-231 BC cells was determined with MTT assay. The MDA-MB-231 cells at logarithmic growth phase were seeded in 96-well plates at a density of $4 \times 10^{4}$ cells per well. Each well contained $100 \mu \mathrm{L}$ of cells in DMEM culture medium. The cells were incubated for $24 \mathrm{~h}$ at 37 ${ }^{\circ} \mathrm{C}$, followed by treatment with different doses of ambrosin viz 8, 16, 32 and $64 \mu \mathrm{M}$ for 24 and 48 h. Untreated wells served as control. Thereafter, $20 \mu \mathrm{L}$ of MTT working solution $(5 \mathrm{mg} / \mathrm{mL})$ was added to the wells which were then further incubated for $4 \mathrm{~h}$. Then, the culture medium in each well was discarded and replaced with 200 $\mu \mathrm{L}$ of dimethyl sulfoxide (DMSO) to dissolve the resultant formazan crystals. The absorbance of each formazan solution was read at $490 \mathrm{~nm}$ in a microplate reader (BioRad, Segrate, Italy).

\section{Analysis of apoptosis in MDA-MB-231 cells}

Following seeding of MDA-MB-231 BC cells at a density of $2 \times 10^{5}$ cells/well in 96-well plates, the cells were exposed to varying doses of ambrosin viz 8,32 and $64 \mu \mathrm{M}$. The plates were then incubated for $24 \mathrm{~h}$. Thereafter, cells in each well were subjected to DAPI staining, followed by rinsing in PBS and fixation in $10 \%$ formaldehyde. Finally, using a fluorescence microscope, the DAPI-stained MDA-MB-231 BC cells were analysed for apoptosis. A similar procedure was followed in annexin V/PI staining assay, except that staining was performed with annexin V/PI (Beyotime, China), and the stained cells were examined via flow cytometry.

\section{Measurement of ROS production}

The MDA-MB-231 cells were cultured in 6-well plates. Post-culture, the cells were treated with ambrosin for $24 \mathrm{~h}$ at doses of 8,32 and $64 \mu \mathrm{M}$. Untreated cells were used as control. The cells in each well were treated with serum-free $10 \mu \mathrm{M}$ dichloro-dihydro-fluorescein diacetate (DCFHDA). Thereafter, the cells were incubated 
for $30 \mathrm{~min}$ at $37^{\circ} \mathrm{C}$. For full contact between the probe and cells, the mixture was re-treated every $4-5 \mathrm{~min}$. Finally, the cells were rinsed twice in PBS, and levels of ROS were calculated via flow cytometry.

\section{Western blotting assay}

Total protein was extracted from cells using lysis with RIPA buffer after the cells were treated with varying doses of ambrosin viz 8, 32 and $64 \mu \mathrm{M}$. The protein content of each lysate was quantified with BCA assay. Then, $40 \mu \mathrm{g}$ of protein from each lysate was separated using SDS-polyacrylamide gel electrophoresis, and transferred to PVDF membranes. The membranes were blocked by incubation with trisbuffered saline Tween (TBST) containing $5 \%$ skimmed milk powder solution for $1 \mathrm{~h}$. Thereafter, the membranes were incubated overnight at $4{ }^{\circ} \mathrm{C}$ with primary antibodies against BAX, BCL-2, cleaved caspase- 3 and caspase-9, $W n$ t3a, and $\beta$-catenin. Then, the membranes were washed three times with TBST before incubating them with horse radish peroxidasecoupled secondary antibody at room temperature for $1 \mathrm{~h}$. Finally, the membranes were re-washed three times with TBST, and the protein bands were developed using enhancedchemiluminescent reagent.

\section{Statistical analysis}

All data are presented as mean \pm SEM. Oneway ANOVA was used for determination of significant differences amongst multiple groups, in addition to Bonferroni and Dunnet post hoc tests (GraphPad Software, USA). Values of $p<$ 0.05 were considered as indicative of statistically significant differences, in relation to control.

\section{RESULTS}

\section{Inhibition of cellular proliferation by ambrosin in MDA-MB-231 cells}

The MTT assay was used to determine the effect of ambrosin on the viability of MDA-MB231 cells. The results demonstrated that ambrosin suppressed the viability of MDAMB$231 \mathrm{BC}$ cells in concentration and time-reliant manner. The percentage cell viability at different concentrations of ambrosin viz 8, 16, 32 and 64 $\mu \mathrm{M}$ were $95,80,50$ and $25 \%$, respectively, after $24 \mathrm{~h}$ of exposure. After $48 \mathrm{~h}$ of drug treatment, the percentage proliferation values were 80,75 , 40 and $10 \%$, respectively, with the proliferation of untreated cells fixed at $100 \%$ (Figure 2).

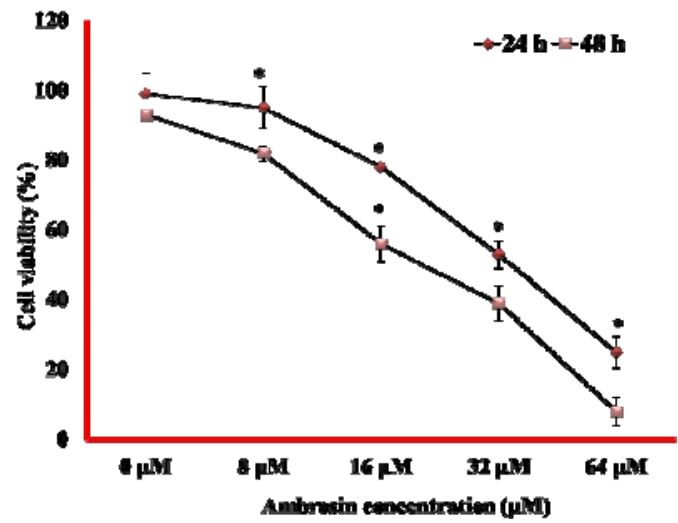

Figure 2: Effect of ambrosin on viability of MDAMB-231 cells. Data from three independent experiments for each ambrosin concentration is shown as mean \pm SEM; ${ }^{*} p<0.05$

\section{Ambrosin induced caspase-dependent apoptotic cell death in MDA-MB231 cells}

The effect of ambrosin on pro-apoptotic cell death in MDA-MB-231 cells was investigated using DAPI and annexin V/PI staining assays. Results from DAPI staining revealed marked dose-dependent increases in the number of apoptotic cells, formation of apoptotic crops, and membrane blebbing. These results are shown in Figure 3.
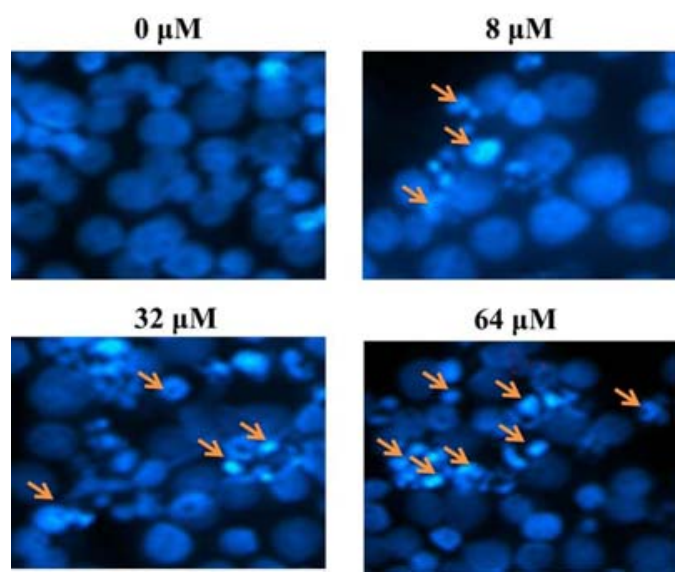

Figure 3: Photomicrographs of DAPI-stained cells presenting apoptotic crops and membrane blebbing at indicated doses

These are the trademarks of apoptosis. Next, the extent of apoptosis was quantified with annexin V/PI staining assay. The results showed that the annexin $\mathrm{V}+/ \mathrm{PI}$ - cells increased from about $5 \%$ in untreated cells, to $24 \%$ in cells treated with ambrosin at a dose of $64 \mu \mathrm{M}$. The annexin $\mathrm{V}+/ \mathrm{PI}+$ cells under same drug concentrations increased from about 7 to $25 \%$ (Figure 4).

Trop J Pharm Res, April 2021; 20(4): 811 


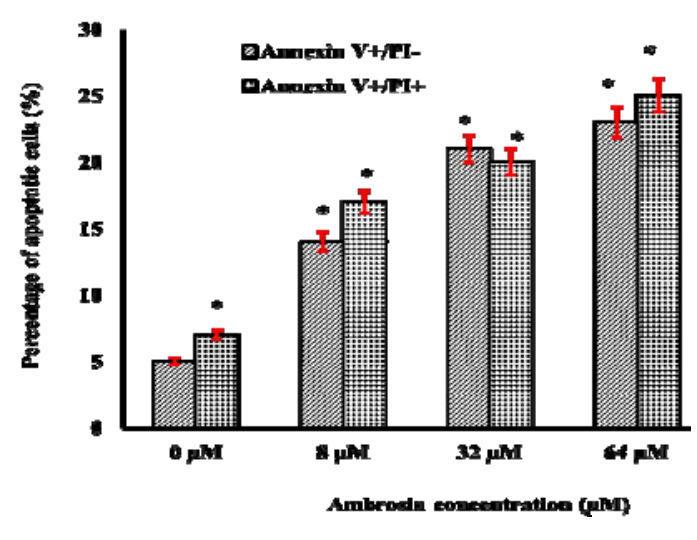

Figure 4: Graphical representation of results from annexin V/PI staining assay showing annexin $\mathrm{V}+/ \mathrm{PI}-$ and annexin $\mathrm{V}+/ \mathrm{PI}+$ apoptotic cells. Data from three independent experiments for each ambrosin concentration are presented as mean $\pm \mathrm{SEM}$; ${ }^{*} p<$ 0.05

Effect of ambrosin on expressions of caspase-3, caspase-9, Bax and Bcl-2

Western blotting assay was used to determine the effect of ambrosin on expression levels of caspase-3, caspase-9, Bax and Bcl-2. Ambrosin significantly and dose-dependently up-regulated the expressions of caspase-3, caspase- 9 and Bax, while Bcl-2 expression was markedly and dose-dependently down-regulated (Figure 5).

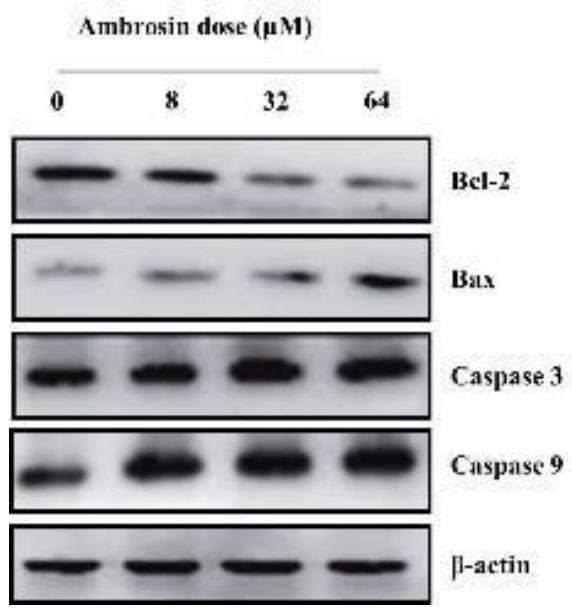

Figure 5: Effect of ambrosin on the expressions of caspase-3, caspase-9, Bax and Bcl-2 in MDA-MB-231 cells, as assayed using western blotting

\section{Ambrosin increased ROS production in MDA-MB-231 cells}

Dichlorofluorescin (DCFH) is non-fluorescent molecule which is transformed to fluorescent DCF by intracellular ROS. Results from DCFHDA staining revealed very low fluorescence in

control cells. However, fluorescence intensity in ambrosin-treated MDA-MB-231 cells increased with increase in ambrosin concentration (Figure $6)$. The levels of ROS at ambrosin doses of 0,8 , 32 and $64 \mu \mathrm{M}$, were 5, 22, 45 and $84 \%$, respectively (Figure 7). The enhanced production of ROS indicated oxidative stressrelated anti-proliferative effects of ambrosin in MDA-MB-231 BC cells.

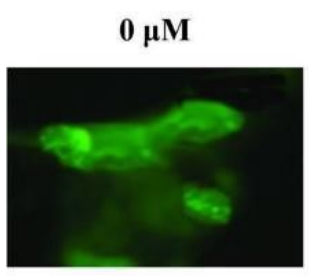

$32 \mu \mathrm{M}$

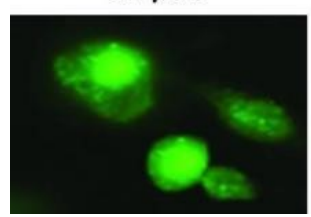

Figure 6: Photomicrographs showing DCFflorescence after ambrosin treatment of MDA-MB-231 BC cells (x 200)

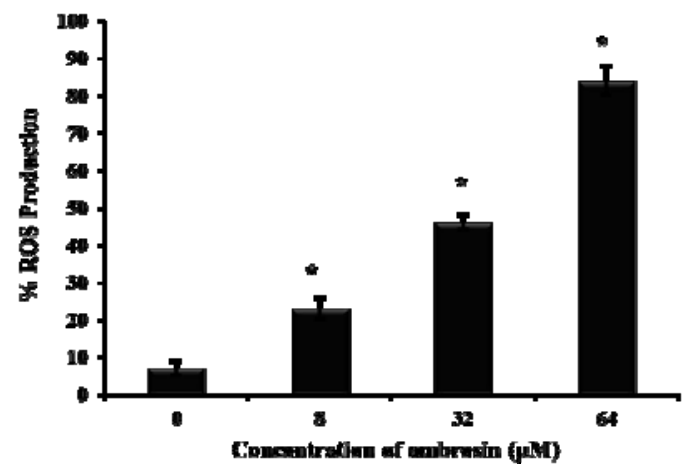

Figure 7: ROS in MDA-MB-231 cells after ambrosin treatment at indicated concentrations. Data from three independent experiments for each concentration group are shown as mean \pm SEM; ${ }^{*} p<0.05$

\section{Suppressive effect of ambrosin on Wnt/beta- catenin signaling}

After ambrosin exposure, MDA-MB-231 BC cells were subjected to western blotting assay for the expressions of Wnt/beta-Catenin signaling pathway proteins. The results indicated dosereliant inhibition of $\mathrm{Wnt} /$ beta-Catenin signaling pathway-allied proteins. There were significant reductions in the levels of $\mathrm{Wnt} 3 a$ and $\beta$-Catenin on exposure of MDA-MB-231 BC cells to ambrosin (Figure 8). 


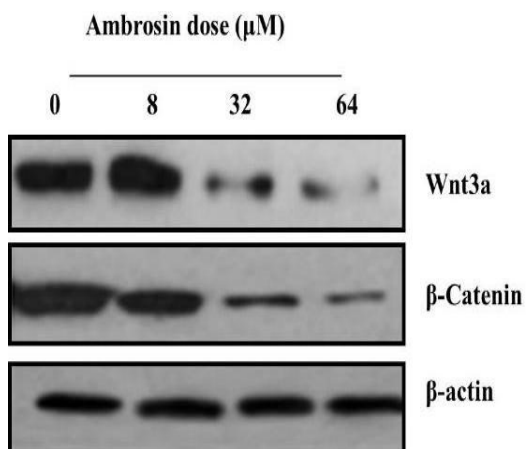

Figure 8: Effect of ambrosin on the expression levels of $\mathrm{Wnt} /$ beta catenin signaling proteins, as assayed using western blotting

\section{DISCUSSION}

Uneven genetic variations that convert a normal cell to a cancer cell are associated with disruption in various intracellular processes. Cancer cells show down-regulated angiogenesis, suppressed apoptosis and rapid cell proliferation. The natural phenomenon of apoptosis is employed to get rid of damaged or malfunctioning cells. Apoptosis progresses through two major pathways: death receptormediated and mitochondrion-mediated pathways. Both pathways are regulated via the caspase cascade. The transformation of a normal cell to a cancer cell results in suppression of apoptosis which increases the chances of survival of cancer cells.

Three distinctive mechanisms are involved in down-regulation of apoptosis during carcinogenesis: disparity in apoptosis-linked proteins, malfunctioning of death receptor signals, and loss of caspase activity. Therefore, targeting of the caspase cascade, $\mathrm{Bcl}-2$ and other apoptosis-allied signaling pathways serves as a key strategy in cancer management. In the current study, the anticancer activity effect of ambrosin sesquiterpene lactone was investigated in drug-resistant human breast cancer cells (MDA-MB-231). In addition, the effect of ambrosin on programmed cell death (apoptosis), ROS production, caspase activation and $\mathrm{Wnt} /$ betaCatenin signaling pathway, were studied. It is already known that ambrosin exerts anti-proliferative effects on different human cancers, including breast cancer cell lines HCC1937, JIMT-1 and MCF-7 [6]. In this study, results from MTT assay revealed significant dose- and time-dependent suppression of proliferation in ambrosin-treated MDA-MB-231 BC cells.

Furthermore, DAPI staining assay revealed production of apoptotic crops and membrane blebbing, indicating that ambrosin induced apoptosis-related cell death in MDAMB-231 cells. Annexin V/PI staining assay showed dosereliant enhancement of annexin $\mathrm{V}+/ \mathrm{PI}-$ and annexin $\mathrm{V}+/ \mathrm{PI}+$ cells. Western blotting revealed that the apoptosis-inducing effect of ambrosin was caspase-dependent and associated with upregulated expression of Bax. It has been previously reported that ambrosin interfered with key signalling processes in cancer cells, thereby promoting apoptosis. A similar study carried out recently showed promising inhibitory potential of ambrosin on the proliferation of breast cancer cells and its pro-apoptotic effects [21]. The findings in this study are similar to previous reports where it was shown that ambrosin inhibited proliferation and enhanced apoptosis.

Ambrosin induced marked and dose-dependent increases in ROS level, as revealed using DCFH-DA staining. Similarly, it has been demonstrated that ambrosin-induced accumulation of ROS in MDA-MB-231 cells enhanced its anti-apoptotic potential [21]. The effects of ambrosin on Wnt/beta-catenin signalling were determined for the first time via western blotting. The results indicated that ambrosin suppressed the expressions of the Wnt/beta-Catenin signaling-associated proteins in a dose-dependent manner.

\section{CONCLUSION}

The results obtained in this study suggest that ambrosin significantly inhibited the proliferation of MDA-MB231 cells. Moreover, ambrosin exerted anti-proliferative effects on MDA-MB231 cells via induction of apoptosis, enhancement of ROS production, caspase activation and downregulation of the Wnt/beta-Catenin signaling pathway. Thus, ambrosin may be a lead molecule in breast cancer research. However, more clinical studies are required to validate this conclusion.

\section{DECLARATIONS}

\section{Conflict of interest}

No conflict of interest is associated with this work.

\section{Contribution of authors}

We declare that this work was done by the authors named in this article and all liabilities pertaining to claims relating to the content of this article will be borne by the authors.

Trop J Pharm Res, April 2021; 20(4): 813 


\section{Open Access}

This is an Open Access article that uses a funding model which does not charge readers or their institutions for access and distributed under the terms of the Creative Commons Attribution License (http://creativecommons.org/licenses/by/ 4.0) and the Budapest Open Access Initiative (http://www.budapestopenaccessinitiative.org/rea d), which permit unrestricted use, distribution, and reproduction in any medium, provided the original work is properly credited.

\section{REFERENCES}

1. Seaman FC. Sesquiterpene lactones as taxonomic characters in the Asteraceae. Bot Rev 1982; 48: 121194.

2. Vazquez-Santillan $K$, Melendez-Zajgla J, JimenezHernandez L, Martinez-Ruiz G, Maldonado V, MartõÂnez-Ruiz $G$, et al. NF-kB signaling in cancer stem cells: a promising therapeutic target? Cell Oncol 2015; 38: 327-339.

3. Hayden MS, Ghosh S. Signaling to NF-kB. Genes Dev 2004; 18: 2195-2224.

4. Abdelgaleil SAM, Badawy MEI, Suganuma T, Kitahara K. Antifungal and biochemical effects of pseudoguaianolide sesquiterpenes isolated from Ambrosia maritima L. Afr J Microbiol Res 2011; 5: 3385-3392.

5. Svensson D, Lozano M, Almanza GR, Nilsson B-O, Sterner $O$, Villagomez $R$. Sesquiterpene lactones from Ambrosia arborescens Mill. inhibit pro-inflammatory cytokine expression and modulate NF-KB signaling in human skin cells. Phytomedicine 2018; 50: 118-126.

6. Sotillo WS, Villagomez $R$, Smiljanic $S$, Huang $X$, Malakpour A, Kempengren S, Rodrigo G, Almanza G, Sterner O, Oredsson S. Anti-cancer stem cell activity of a sesquiterpene lactone isolated from Ambrosia arborescens and of a synthetic derivative. PloS ONE 2017; 12(9): e0184304.

7. Villagomez R, Collado J, Muñoz E, Almanza G, Sterner O. Natural and Semi-Synthetic Pseudoguaianolides as Inhibitors of NF-KB. J Biomed Sci Eng 2014; 7(10): 83347.

8. Khalil MNA, Choucry MA, El Senousy AS, Hassan A, ElMarasy SA, El Awdan SA, Omar FA. Ambrosin, a potent $N F-\kappa \beta$ inhibitor, ameliorates lipopolysaccharide induced memory impairment, comparison to curcumin. PLoS ONE 2019; 14(7): e0219378.

9. Safaee A, Zeighami B, Tabatabaee HR, Moghimi Dehkordi B. Quality of life and Related Factors in Breast
Cancer Patients under Chemotherapy. Iran J Epidemiology 2008; 3(4): 61-66.

10. Forouzanfar MH, Foreman KJ, Delossantos AM, Lozano $R$, Lopez AD, Murray CJL, Mohsen Naghavi M. Breast and cervical cancer in 187 countries between 1980 and 2010: a systematic analysis. Lancet 2011; 378: 14611484.

11. The Globocan Project. Available at: http://www.globocan.iarc.fr. [accessed July19, 2016].

12. Hedenfalk IA, Ringner M, Trent JM, Borg A. Gene expression in inherited breast cancer. Adv Cancer Res 2002; 84: 1-34.

13. Coates AS, Winer EP, Goldhirsch A, Gelber RD, Gnant $M$, Piccart-Gebhart $M$, Thürlimann $B$, Senn $H$-J. Tailoring therapies-improving the management of early breast cancer: St Gallen International Expert Consensus on the Primary Therapy of Early Breast Cancer 2015. Ann Oncol 2015; 26: 1533-46.

14. Sims $A H$, Howell A, Howell SJ, Clarke RB. Origins of breast cancer subtypes and therapeutic implications. Nat Clin Pract Oncol 20017; 4: 516-525.

15. Rao CV, Rivenson A, Simi B, Reddy BS. Chemoprevention of colon carcinogenesis by dietary curcumin, a naturally occurring plant phenolic compound. Cancer Res 1995; 55(2): 259-266.

16. Rao CV, Rivenson A, Simi B, Zang E, Kelloff G, Steele V, Reddy BS. Chemoprevention of colon carcinogenesis by sulindac, a nonsteroidal anti-inflammatory agent. Cancer Res 1995; 55(7): 1464-1472.

17. Chinery R, Beauchamp RD, Shyr Y, Kirkland SC, Coffey RJ, Morrow JD. Antioxidants reduce cyclooxygenase-2 expression, prostaglandin production, and proliferation in colorectal cancer cells Cancer Res 1998; 58.11: 2323-2327.

18. Lee E, Park KK, Lee JM, Chun KS, Kang JY, Lee SS, Surh Y. Suppression of mouse skin tumor promotion and induction of apoptosis in HL-60 cells by Alpinia oxyphylla Miquel (Zingiberaceae)", Carcinogenesis 1998; 19(8): 1377-1381.

19. Khursheed A, Rather MA, Rashid R. Plant-based natural compounds and herbal extracts as promising apoptotic agents: their implications for cancer prevention and treatment. Adv Biomed Pharma 2016; 3(4): 245-269.

20. Lee E, Surh YJ. Induction of apoptosis in HL-60 cells by pungent vanilloids,[6]-gingerol and [6]-paradol. Cancer Lett 1998; 134(2): 163-168.

21. Fan S, Cui Y, Hu Z, Wang W, Jiang W, Xu H. Ambrosin sesquiterpene lactone exerts selective and potent anticancer effects in drug-resistant human breast cancer cells (MDA-MB-231) through mitochondrial mediated apoptosis, ROS generation and targeting Akt/B-Catenin signaling pathway. JBOUN 2020; 25(5): 2221-2227. 